\title{
The Influence of Work Environment, Workload and Competence against Account Representative Performance at DGT in West Jakarta Regional Tax Office
}

\author{
Ai Hermayati ${ }^{1}$, Farida Elmi ${ }^{2}$ \\ \{ai.hermayati@gmail.com¹, farida.elmi@mercubuana.ac.id² \\ Universitas Mercubuana, Jakarta, Indonesia ${ }^{12}$
}

\begin{abstract}
This research aims to measure the impact of work environment, workload and competence on the performance of Account Representative at West Jakarta Regional Tax Office. This research included in quantitative. The sample research was 80 Account Representatives from DGT in West Jakarta Regional tax Office. The data analysis used multiple linear regression analysis. The results of multiple linear regression analysis shows that work environment, workload and competence partially had positive and significant impact towards the performance of Account Representative. The test results shows that work environment, workload and competence simultaneously had positive and significant influence towards account representative performance.
\end{abstract}

Keywords: Work environment, workload, competence, Performance

\section{Introduction}

\subsection{Background of Problem}

Almost all countries in the world taxed its citizens to survive of the country, including developed countries. The phenomenon of Indonesia's economic activities which inseparable from the role of taxes in it. Taxes have become the backbone of state finances. Tax contribution to state income has increasingly vital. In 2018 State Budget posture, tax revenue had contributed 82.5 percent from total state revenue. The Directorate General of Taxes, here in after written by DGT is one of the government agencies which have an important role in state revenue. In carrying out its mission, the Directorate General of Taxes always maintains the principle that HR is the most valuable asset, so the Directorate General of Taxes should capable to motivate its employee to be able to do their best for the nation in optimized the State revenue. Performance of Institutional and employee are two things that need each other, if employee succeed in bringing progress to the institution, the benefits obtained will be reaped by both parties.

DGT in West Jakarta Regional Office is implements element or vertical agency within Directorate General of Taxes. West Jakarta Regional Tax Office has 0 topple of 11 tax offices where the KPP carried out all tax services to the public or directly related to taxpayers. To explore those factors from organizational behavior which had influence on Account Representative performance in the West Jakarta Regional Tax Office, the 
researchers conducted a pre-survey research by distributing questionnaires to Account Representatives. The results obtained from these pre-survey shows that the performance (AR) at West Jakarta Regional Tax Office was influenced by various factors but there are 3 (three) variables that indicate there had problems such as: work environment, workload and competence, while according to organizational performance data at DGT in West Jakarta Regional tax office that always been achieved and even has an increase in 2018

Table 1. Report on Organizational Performance Values for 2016 to 2018

\begin{tabular}{|c|c|c|c|}
\hline & 2016 & 2017 & 2018 \\
\hline Organizational Performance Value & $102,65 \%$ & $102,22 \%$ & $109,96 \%$ \\
\hline
\end{tabular}

Source: NKO Kanwil Report (2020)

Based on these pre-surveys result it was states that there are several factors that indicate problems including work environment factors, workload factors and competency factors. However, a research was conducted by [1] which found that compensation has no impact on employee performance. Then, research which conducted by [2] which found that physical factors from work environment had no impact on employee performance. Meanwhile, research which conducted by [3] shows that workload had directly positive and significant impact on employee performance. Based on these background and gap phenomena as well as research gaps which has been described above, the researchers were interested to do further research with tittle "The Influence of Work Environment, Workload and Competence against Account Representative Performance at Directorate General of Taxation in West Jakarta Regional Tax Office".

\subsection{Work Environment}

The work environment is something from work environment that makes work easier or difficult [4]. Meanwhile, according to [5], work environment is everything surrounds the workers in which could them in carrying out his tasks. According to Sarwoto in Sidanti, there are two dimensions of work environment, which is physical work environment and nonphysical work environment [4].

\subsection{Workload}

Based on [6], workload is the amount of work that should be performed by an organizational unit. Meanwhile, the Ministry of Administrative and Bureaucratic Reform explained that workload is a number of work targets or target results that need to achieved within a certain time [7]. To measure workload, there are 3 dimensions that might be related to performance, such as time load, mental effort load, and psychological stress load.

\subsection{Competence}

According to the Regulation of the Minister of Finance in the Republic of Indonesia, competence is a grouping of knowledge, skills and attitudes which manifested in form of behavior that shows the ability to manage work and build interactions with other people, which determines someone success at work [9]. furthermore continued, Sedarmayanti explained that competence includes in various technical and non-technical factors, personality and behavior, soft skills and hard skills. To measure a person's competence, it is necessary to pay attention to the competence characteristics that exist in person, such as motives, traits, knowledge, skills and self-concept [10]. 


\subsection{Performance}

According to the laws of Minister of Finance, performance is the result of implementation the duties and functions of the organization and employee during a certain period [11], therefore it is necessary to have a performance appraisal. Performance appraisal is a system of periodic assessments of employee performance that supports organizational success or related to the implementation of their duties [12]. To measure the employee performance in government agency or organization, it is necessary to pay attention to employee work performance and employee behavior [11]. Theoretical framework in this research could be described as follows:

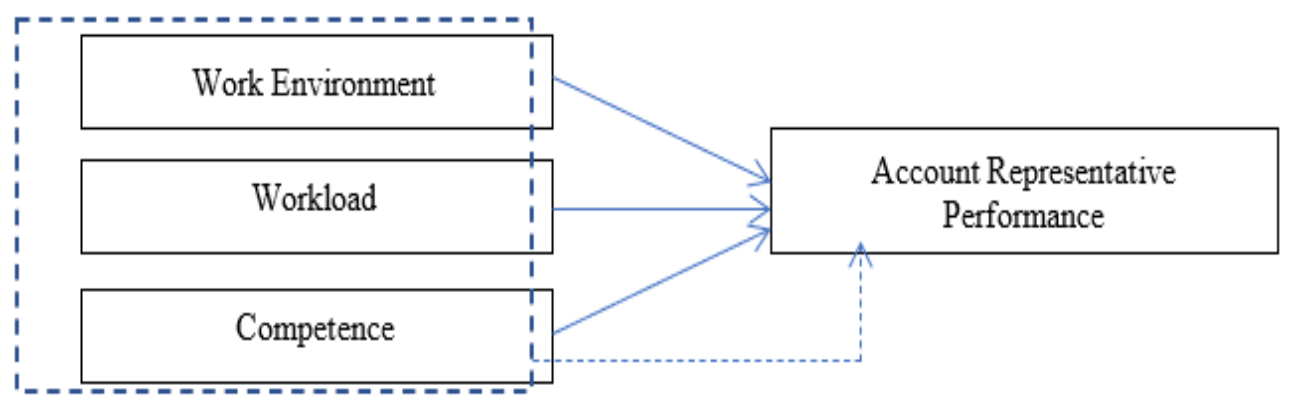

Fig 1. Theoretical Framework

Based on these phenomena and theoretical framework also theories which have been presented previously, The authors could formulate several hypothesis that will examined in this research such as: Work environment had positive impact on account representative performance; workload had positive impact on account representative performance; competence had positive impact on account representative performance; and work environment, workload, and competence simultaneously influence on account representative performance.

\section{Research Method}

This research used quantitative method with causality approach to explain those causal connection between these variables studied. The independent variables in this research consist of work environment, workload and competence, while the dependent variable was account representative performance. The population were all Account Representatives on DGT at West Jakarta regional tax office which amounted of 397. The sampling technique used side purposive. Sample gathered used non-probability sampling with assist by Slovin formula so the sample gathered was 80 respondents. The Researchers used multiple linear regression analysis techniques (multiple regression) by SPSS 25 software program to test those hypotheses. 


\section{Results and Discussion}

The validity test used to measure validity of questionnaire. While the reliability test used to examine those reliability of the disclosure tools from data. Based on these validity test results, it is known that each question had r-count value (person correlation) more than the ttable value of 0.2199 , therefore it could be concluded that each question indicator was valid. Based on these reliability test, its known that Cronbach's Alpha value for work environment variable was 0.899 , the workload variable was 0.890 , the competency variable was 0.909 and the Account Representative performance variable was 0.938 . The conclusion from these reliability tests was Cronbach's Alpha value for each variable exceeds 0.6, meaning that all variables were reliable.

Classic assumption test used as basis for getting good regression results. In this research, the normality test, multicollinearity test and heteroscedasticity test were used. Based on these normalize test results with Kolgomorov-Smirnov Test, it shows that significant value of $0.200>0.05$, then if we look at its histogram, it shows a normal distribution pattern, the normal probability plot graph was also shows the data (points) spread out around the diagonal line and follow the direction of the diagonal line, then the regression model fulfills the normality assumption, Meaning that these data was normally distributed.

Meanwhile, based on these multicollinearity test results, it is known that tolerance value for the work environment variable was 0.654 with vif value was 1.528 , the workload variable had tolerance value of 0.444 with vif value of 2.250 and the competency variable had tolerance value of 0.428 and vif value of 2,336, so it could be concluded that these three independent variables had tolerance value greater than 0.10 and a vif value less than 10 , Therefore it could said that there's no multicollinearity between independent variables. After these normality and multicollinearity tests were carried out, the classic assumption test which author did was heteroscedasticity test. The scatterplots graph in heteroscedasticity test shows that the dots spread randomly both above and below the number 0 on $\mathrm{Y}$ axis and do not form a certain regular pattern, so it can be concluded that heteroscedasticity did not occur.

Linear regression used to measure the strength of connection between two or more variables, it also shows the direction of the strength of relationship between the dependent and independent variables. Based on these test results, it is known that the value from variable constant $(\alpha)$ was 1.034 , then the coefficient of the independent variable (b), such as work environment was 0.189 , workload was 0.343 and competence was 0.268 , the regression equation that could be arranged as follows:

$$
\mathrm{Y}=1.034+0.189 \mathrm{X} 1+.343 \mathrm{X} 2+.268 \mathrm{X} 3+\mathrm{e}
$$

Table 1. Multiple Linear Regression Analysis

\begin{tabular}{|c|c|c|c|c|c|}
\hline \multirow[b]{2}{*}{ Model } & \multicolumn{2}{|c|}{$\begin{array}{l}\text { Unstandardized } \\
\text { Coefficients }\end{array}$} & \multirow{2}{*}{$\begin{array}{c}\text { Standardized } \\
\text { Coefficients } \\
\text { Beta }\end{array}$} & \multirow[b]{2}{*}{$\mathrm{t}$} & \multirow[b]{2}{*}{ Sig. } \\
\hline & $\mathrm{B}$ & Std. Error & & & \\
\hline (Constant) & 1.034 & .382 & & 2.710 & .008 \\
\hline Work Environment & .189 & .089 & .186 & 2.120 & .037 \\
\hline Workload & .343 & .076 & .479 & 4.491 & .000 \\
\hline Competence & .268 & .128 & .227 & 2.089 & .040 \\
\hline $\mathrm{F}$ & & & & 40.680 & .000 \\
\hline $\mathrm{R}^{2}$ & & & .616 & & \\
\hline
\end{tabular}


Based on the t-test value, these following results were obtained:

a. Test results with SPSS 25 on work environment variables obtained that t- value of 2.120 was greater than $t$-table value of 1.99167 with significance of $0.037 \leq 0.05$, meaning that it was significant, so work environment partially had positive and significant influence towards Account Representative Performance.

b. Test results with SPSS 25 on workload variables had obtained t value 4.491 which greater than $\mathrm{t}$ table 1.99167 with significance of $0.000 \leq 0.05$, meaning that was significant, therefore workload partially had positive and significant impact on Account Representative Performance.

c. Test results with SPSS 25 on Competence variable obtained t value 2.089 which greater than $\mathrm{t}$ table value 1.99167 with significance of $0.040 \leq 0.05$, meaning that it was significant, so competence partially had positive and significant impact on Account Representative Performance.

d. Based on F-test result (ANOVA), it shows that significance value was 0.000 which less than $\alpha=0.05$ or determination model shows that F-counts value was 40.680 with probability (significance) of 0.000 , meaning that probability value was $\leq 0.05$, while the results obtained from the $F$ table was 2.72 , which means that $F$ count $\geq F$ table $(40,680 \geq$ 2.72). So, this regression model can be used to predicted Account Representative performance or could be said that Work Environment, Workload and Competence variables simultaneously impact on Account Representative Performance or the model was right. According to coefficient of determination, it shows that $\mathrm{R}$ Square value (coefficient of determination) was 0.616 or $61.6 \%$, meaning that Account Representative performance variables could be explained by work environment variables, workload and competence while the remaining $38.4 \%(100 \%$ - 61.6\%) could be explained by other variables outside these research variables.

Based on the results from this correlation analysis between dimensions, it has the results that:

a. There had strong and positive correlation of 0.537 between non-physical dimensions and the dimensions of employee work performance. This means that comfort in working was supported by non-physical work environment such as a good work structure, work responsibilities, cooperation between groups, smooth communication, attention and support from leaders would increase the achievement of employee work goals according to predetermined targets.

b. There had strong and positive correlation of 0.737 between the dimension of time load and the dimension of work behavior. Meaning that the amount of time given to planning, implementing and monitoring tasks or jobs by account representative, if its managed properly, it will have an impact and increasing the performance.

c. There had strong and positive correlation of 0.609 between the dimensions of selfconcept and work behavior. Meaning that if account representative has a good selfconcept, attitude, value and image, it will be reflected in work behavior.

Based on these $t$ test calculation result of work environment variable, its obtained that $t$ value of 2.120 was greater than $t$ table value of 1.99167 which has significance of $0.037 \leq$ 0.05 , so it could be concluded that work environment partially had positive and significant impact on account representative performance. This shows that work environment had positive connection with performance. Meaning that comfortable work environment will impact to account representative performance. According to the research that has been done, it is known that non-physical work environment is more dominant than physical work environment. This proved that non-physical work environment which includes work 
structure, work responsibilities, leadership attention and support, cooperation between groups, smooth communication between friends and superiors, had greater influence on account representative performance compared to physical work environments does. Personal relationships between employee and superior will be able to have big influence on the improvement of account representative performance. The results of these research were in line with Sunyoto's theory, which states that the work environment is everything that surrounds the worker which could impact him / her in carrying out the assigned tasks [5]. The results from this research were in line with prior research which show that work environment had positive impact on employee performance [13].

Based on these t-test calculation result from workload variable, the $t$ count value of 4.491 which greater than $t$-table value of 1.99167 which had significance of $0.000 \leq 0.05$, Meaning that it was significant. Workload had positive and significant impact on account representative performance. These accounts representative position is responsible to providing excellent service to taxpayers and at the same time increasing the tax revenue. Alongside with the increasing in the number of registered taxpayers and the increase in tax revenue targets, it is a challenge for them to improving their performance. This evident from this research that workload had positive impact on account representative performance. This were in line with theory of Robbins \& Judge, which stated that positive negative workload is a perceptual problem which understood by employee [14]. If employee considers the workload as problem, the work will not be completed properly but if the employee considers the workload as a challenge then the employee will be serious and enjoy all the tasks which assigned to them. The results of this research were in line with prior research which shows that workload directly had positive and significant impact on performance [3].

Based on the $t$ test calculation results on competency variable, it was obtained that the $t$ value of 2.089 which greater than the t-value of 1.99167 and significance of $0.040 \leq 0.05$, meaning that it was significant, in other words, competence had positive and significant impact on Account Representative Performance. The duty from Account Representative is to provide services, supervise, direct and provide direct consultation to taxpayers. Therefore, the ability and high quality from Account Representative is needed so it would improve the performance. This in line with Sedarmayanti's theory which stated that competence includes various technical and non-technical factors, personality and behavior, soft skills and hard skills [10]. This were in line with previous research that shows that competence had positive and significant impact on employee performance [15].

\section{Conclusions}

Based on these research results, data analysis and discussion about work environment, workload and competence towards account representative performance at West Jakarta Regional Tax Office, it could be concluded that:

Work environment had positive and significant impact on account representative performance; Workload had positive and significant impact on account representative performance; Competence had positive and significant impact on account representative performance; and work environment, workload and competence together had positive and significant impact on account representative performance at DGT in West Jakarta Regional Office

By considering these research results which has been done previously, then researcher could draw several suggestions which are expected to be useful for agencies so as to improve for further research, such as: Suggestion for leaders with hoped that the agency will create a 
conducive and family-like work environment because it has positive impact on improving performance by holding an event / program which involves all employee every 6 months so as to create intimacy and synergy among employee, both colleagues and superiors for example by doing outbound. Agency leaders need to consider the dimensions which had low value, such as physical work environment by improving facilities and infrastructure that support employee comfortless feeling at work, by increasing the number of ventilators and air conditioners so these physical work environments could improve the non-physical work environment in order to improving the performance of Account Representative. Agencies could provide in-house training on time management for Account Representatives at least once every 3 months, because the timing of completing work if its managed properly it would have positive impact on improving the performance of Account Representatives.

For dimensions which had low value, which is the psychological pressure dimension of load, it is expected that the agency will provide seminars motivation or workshops once a month, spiritual flushes or religious activities in order to minimize stress or frustration on employee. These programs were expected to foster employee motivation so the jobs that previously considered as burden become a challenge and should be completed properly. For a dimension which had a low value, which is Knowledge dimension, the leader could assign those Account Representative staff in shift to attend seminars, educational activities and training that adjust the times so one of visions from DGT West Jakarta Regional Office could be realized, namely realizing competent human resources and integrity.

Based on this research $61.6 \%$ from Account Representative performance variables that could be explained by work environment variables, workload, and competence while 38.4 NKO Kanwil Report (2020)\% were explained by other variables outside these research variables that's why as for further researchers need adding more or replace independent or dependent variables that might have influence on Account Representative performance as well as increasing the number of samples or research sites which are wider spread so the research could be properly generalized.

\section{References}

[1] Rahardjo, S. (2014). The Effect of Competence, Leadership and Work Environment Towards Motivation and its Impact on the Performance of Teacher of Elementary School in Surakarta City, Central Java, Indonesia. International Journal of Advanced Research in Management and Social Sciences, 3(6).

[2] Njenga, S. G., \& Waiganjo, M. (2015). Effect of Workplace Environment on the Performance of Commercial Banks Employees in Nakuru Town. International Journal of Managerial Studies and Research, 3(12), 76-89.

[3] Harini, S. S., \& Kartiwi, N. (2018). Workload, Work Environment and Employee Performance of Housekeeping. International Journal Of Latest Engineering And Management Research, 03(10), 15-22.

[4] Sidanti, H. (2015). Pengaruh lingkungan Kerja, Disiplin Kerjadan MotivasiKerja Terhadap Kinerja Pegawai Negeri Sipil di Sekretariat DPRD Kabupaten Madiun. Jurnal Jibeka, 9 (1), 44- 53.

[5] Sunyoto, D. (2013). Manajemen Sumber Daya Manusia. CAPS (Center of Academic Publishing Service). Yogyakarta.

[6] Kementerian Keuangan Repoblik Indonesia. (2016). Peraturan Menteri Keuangan Republik Indonesia Nomor 175/PMK.01/2016 Tentang Pedoman Pelaksanaan Analisis Beban Kerja (Workload Analysis) di Lingkungan Kementerian Keuangan.

[7] Kementerian Pendayagunaan Aparatur Negara Republik Indonesia. (2004). Keputusan Menteri Pendayagunaan Aparatur Negara, Nomor KEP/75/M.PAN/7/2004 Tentang Pedoman 
Perhitungan Kebutuhan Pegawai Berdasarkan Beban Kerja Dalam Rangka Penyusunan Formasi Pegawai Negeri Sipil.

[8] Tarwaka. (2015). Ergonomi Industri Dasar-dasar Pengetahuan Ergonomi dan Aplikasi di Tempat Kerja. Harapan Press. Surakarta.

[9] Kementerian Keuangan Republik Indonesia. (2014). Peraturan Menteri Keuangan Republik Indonesia Nomor 38/PMK.01/2014 Tentang Penyampaian Laporan Individual Assessment Center di Lingkungan Kementerian Keuangan.

[10] Sedarmayanti. (2016). Manajemen Sumber Daya Manusa, Reformasi Birokrasi dan Manajemen Pegawai Negeri Sipil. Refika Aditama. Bandung.

[11] Kementerian Keuangan Republik Indonesia. (2014). Keputusan Menteri Keuangan Republik Indonesia Nomor 467/KMK.01/2014 Tentang Pengelolaan Kinerja di Lingkungan Kementerian Keuangan.

[12] Elmi, F. (2018). Telisik Manajemen Sumber Daya Manusia. Jakarta. Mitra Wacana Media.

[13] Riyanto, S., Sutrisno, A., \& Ali, H. (2017). The Impact of Working Motivation and Working Environment on Employees Performance in Indonesia Stock Exchange. International Review of Management and Marketing, 7(3).

[14] Robbins, S.P., \& Judge, T.A. (2014). Perilaku Organisasi. Jakarta. Salemba Empat.

[15] Triadhy, W., Elmi, F., \& Aima, M.H. (2020). The Effect of Competence and Transformational Leadership Style on The Motivation and Its Implications on Teachers Performance at 01 and 02 North Petukangan Elementariy School. Dinasti International Journal of Education Management and Social Science, 1(3). 